\title{
Proqram Mühəndisliyinin Tədrisi Üzrə Beynəlxalq Təşkilatların Tövsiyələri
}

\author{
Zəfər Cəfərov \\ Azərbaycan Texniki Universiteti \\ zafar.cafarov@bk.ru
}

\begin{abstract}
Xülaso- İşdə proqram mühəndisliyinin tədrisi üzrə bəzi beynəlxalq təşkilatların tövsiyələri təhlil olunur. Təhsilin səmərəli təşkili üçün nəzərdə tutulan "SE2004" adlı tövsiyələr toplusu haqqında məlumtlar verilir.
\end{abstract}

Açar sözlor-proqram mühəndisliyi, todris planı, kompetensiya

\section{GİRIŞ}

Ciddi proqramlaşdırma məhsulları milli sərvət kimi qiymətləndirilir və onların tərtibatçılarının müəlliflik hüquqları qorunur. Hər bir istehsal növü kimi proqramlaşdırma məhsulları da kustarılıqdan başlamış və müasir sənaye səviyyəsinə qədər yol keçmişdir. Müasir sənaye səviyyəsini primitiv proqramlaşdırmadan fərqləndirən cəhətlər mövcuddur: əmək bölgüsü, elm, müasir texnologiya, standartların istifadə olunması və keyfiyyətli nəticə. Bu cür bilik və bacarıqlar isə özlüyündə deyil, təhsil sayəsində qazanılır. Ona görə də proqram mühəndisliyi ixtisası üzrə kadr hazırlığı alimlərin, pedaqoqların, həm də informasiyakommunikasiya texnologiyaları üzrə mütəxəssislərin qarşısında mühüm vəzifələr qoyur. Bu vəzifələrin mahiyyətinə görə proqram mühəndisliyinə təkcə inkişaf ənənəsinin elementi kimi baxilmamalı, tədrisin keyfiyyətinin yüksədilməsi istiqamətində vacib məqsədlərə nail olmaq üçün geniş tədqiq olunmalı, bu sahə üzrə beynəlxalq təşkilatların tövsiyələri öyrənilməlidir.

\section{BEYNOLXALQ TəŞKİLATLARIN TÖVSIYYLӘRİ}

Dünya universitetlərində təhsil alanlar üçün proqram mühəndisliyi (Software Engineering) üzrə informatika və kompüter mühəndisliyi təlimini tamamlayan təhsil proqramları hazırlanır. ACM (Association for Computing Machinery) və IEEE CS (Institute of Electrical and Electronics Engineers, Computer Society) kimi nüfuzlu beynəlxalq təşkilatlar hesablama texnikası üzrə kurrikulum (Computing Curriculum) layihəsi çərçivəsində səmərəli tədris planı tərtib etmək üçün Software Engineering 2004 (SE2004) tövsiyələr toplusunu dərc etmişdir. SE2004 proqram mühəndisliyindən əlavə informatika və kompüter mühəndisliyi, informasiya texnologiyaları, informasiya sistemləri də daxil olduğu kompüter təlimatını (Computing Discipline) əhatə edən sənədlərdən biridir. $\mathrm{Bu}$ sənəd aşağıdakı strukturda hazırlanmışdır [1]:

\section{Giriş (Introduction);}

2. Proqram mühəndisliyi üzrə istiqamətlər (The Software Engineering Discipline);

3. Tərtibat prinsipləri (Guiding Principles);
4. Proqram mühəndisliyi sahəsi üzrə təhsilin məzmunu (Overview of Software Engineering Education Knowledge);

5. Proqram mühəndisliyi üzrə tədris planın layihələndirilməsi və tərtibatı üçün təlimat (Guidelines for $S E$ Curriculum Design and Delivery);

6. Tədris fənləri və onların ardıcıllığg (Courses and Course Sequences);

7. Alternativ mühitlərə uyğunlaşma (Adaptation to Alternative Environments);

8. Təhsil proqramının reallaşdırılması və qiymətləndirilməsi (Program Implementation and Assessment).

SE2004 tövsiyələr toplusu proqram mühəndisliyinin eyni zamanda kompüter (Software Engineering as a Computing Discipline) və mühəndislik (Software Engineering as an Engineering Discipline) təlimlərindən ibarət olmasını şərh edən icmal (Introduction) ilə başalanır. Sonra sənədin tərtibat prinsipləri açiqlanır (Guiding Principles), proqram mühəndisliyinin anlayışları (Definitions of Software Engineering), mühəndislik xarakteristikaları (Characteristics of Engineering) və təlim fəaliyyətində tələbələrin əldə edəcək nəticələri (Student Outcomes) sadalanır. Tövsiyələrdən əlavə təlimin ümumi prinsipləri, fənnlərin ardıcıllığ 1 (Course Sequences) vo poqramlar1 (Course Description), todris planı nümunələri (Guidelines for SE Curriculum Design and Delivery), tədrisin təşkili üzrə infrastuktur və resurslar (Curriculum Resources and Infrastructure) və keyfiyyətin qiymətləndirilməsi məsələləri (Assessment and Accreditation Issues) haqqinda zəruru məlumtatlar sənədə daxil olunmuşdur.

Sənədin müxtəlif təhsil və univeristet mühitinə uyğunlaşması (Adaptation to Alternative Environments) üçün xüsusi tövsiyələr verilmişdir.

SE2004 tövsiyələrin əsas hissəi təhsil müəssisəsinin tədris planı üzrə proqram mühəndisliyi üçün təlim prosesində təqdim etmoli bilikləri (Software Engineering Education Knowledge, SEEK) təfsilatı əks etdirir.

Proqram mühəndisliyi sahəsi üzrə təhsilin məzmunu (Overview of Software Engineering Education Knowledge) SE2004 tövsiyələr toplusununun dördüncü fəslində aşağıdak1 strukturda əks olunur:

- Proqram mühəndisliyi sahəsi üzrə təhsilin məzmununun toyini prosesi (Process of Determining the SEEK); 
- Bilik sahələri, modullar və mövzular (Knowledge Areas, Units, and Topics);

- Osas materiallar (Core Material);

- Tədrisə ayrilan akademik saatlar (Unit of Time);

- SEEK ilə tədris planları arasında əlaqə (Relationship of the SEEK to the Curriculum);

- Bilik sahələrinin seçilməsi (Selection of Knowledge Areas);

- Proqram mühəndisliyi ixtisası üzrə bilik sahələri ( $S E$ Education Knowledge Areas);

- Hesablamanın əsasları (Computing Essentials);

- Riyaziyyat və mühəndisliyin əsasları (Mathematical and Engineering Fundamentals);

- Peşə (istehsalat) təcrübəsi (Professional Practice);

- Proqram təminatının modelləşdirilməsi və analizi (Software Modeling and Analysis);

- Proqram təminatının layihələndirilməsi (Software Design);

- Proqram tominatının yoxlanmasi (Software Verification);

- Proqram təminatının inkişafi (Software Evolution)

- Proqram təminatının hazırlanması prosesi (Software Process);

- Proqram təminatının keyfiyyəti (Software Quality);

- Proqram tominatının idaro olunmasi (Software Management);

- Sistem və tətbiqi proqram təminatı üzrə ixtisaslaşmalar (Systems and Application Specialties).

Proqram mühəndisliyi (software engineering) dinamik şəkildə dəyişən peşə sahəsi olduğu üçün onun universitetlərdə tədrisinə dair tövsiyyələrdən ibarət olan yeni SE2014Proqram mühəndisliyi 2014: bakalavrlar üçün proqram mühəndisliyi sahəsi üzrə tədris proqramı sənədini işləmişlər [2].

\section{PROQRAM MÜHӘNDİSLIYİ KOMPETENSIYYASINA QOYULAN TOLӘBLӘR}

SE2004 tövsiyələrinə görə təhsil proqramının mənimsənilməsi nəticəsində məzunun kompetensiyasına (Student Outcomes) aşağıdakı tələblər qoyulur:

- proqram mühəndisi kimi əmək fəaliyyətinə (praktik işə) başlamaq üçün zəruri olan bilik və bacarıq nümayiş etdirmək;

- keyfiyyətli proqram məhsulu hazırlanmasında fərdi və qrup daxilində fəaliyyət göstərmək;

- «məsrəf, vaxt, bilik, mövcud sistem və təşkilat» üzrə yaranmış məhdudiyyətlər daxilində məqbul kompromislər axtarmaq.

- «etik, sosial, hüquqi və iqtisadi maraqları» nəzərə almaqla proqram mühəndisliyi yanaşmalarından istifadə edərək bir və ya bir neçə təyinat sahəsi üzrə layihələr hazirlamaq;

- proqram mühəndisliyi üçün zəruri olan nəzəriyyə, model və metodların dərkini və tətbiqini nümayiş etdirmək;

- səmərəli iş metodlarını, ünsiyyət və liderlik kimi keyfiyyətləri nümayiş etdirmək;

- yeni yaranan texnologiya, model və metodları izləmək və mənimsəmək.

Azərbaycan universitetlərində proqram mühəndisliyi ixisası üzrə mütəxəssis hazırlı̆̆gi aparılmır. Ali təhsilin bakalavriat səviyyəsi ixtisaslarının (proqramlarının) təsnifatına aid "Kompüter mühəndisliyi", "İnformasiya texnologiyaları", "Sistem mühəndisliyi" və "Kompüter elmləri" ixtisasları üzrə tədris planlarına proqram mühəndisliyinin müxtəlif aspektlərini əks etdirən fənlər daxil edilmişdir. $\mathrm{Bu}$ tədris planların və fənn proqramların məzmununda, ümumilikdə akademik təhsilin təşkilində SE2014 tövsiyələrin nəzərə alinması vacibdir.

\section{NӘTİCə}

Proqram mühəndisliyi sahəsində mütəxəssislər böyük və mürəkkəb proqram sistemləri üzrə tələbləri təhlil etmək, layihələndirmək, idarə etmək və keyfiyyəti qiymətləndirmək qabiliyyətinə malik olmalıdırlar $\mathrm{Bu}$ tələblərin yerinə yetirilməsi üçün SEEK üzrə təklif olunan materilların mənimsənilməsi vacibdir.

\section{ӘDӘBIYYAT}

[1] Software Engineering 2004: Curriculum Guidelines for Undergraduate Degree Programs in Software Engineering, tech. report, IEEE CS and ACM, 2004; A Volume of the Computing Curricula Series, ACM, 2004, Vol. 8, p.129. http://sites.computer.org/ccse/SE2004Volume.pdf

[2] Software Engineering 2014: Curriculum Guidelines for Undergraduate Degree Programs in Software Engineering A Volume of the Computing Curricula Series, ACM, 2015, Vol. 1, p.1340. https://www.acm.org/education/se2014.pdf 